Vol. 11 (2002): 59-74.

\title{
Efficiency of split nitrogen fertilization with adjusted irrigation on potato
}

Paavo Kuisma

Potato Research Institute, Ruosuontie 156, FIN-16900 Lammi, Finland, e-mail: paavo.kuisma@petla.fi

The split application of fertilizer nitrogen and adjusted irrigation were studied at Potato Research Institute in Lammi in 1993-1995. Independent of year, variety or irrigation, the split application of nitrogen had no benefit on yield or yield quality compared to a single dose at planting on the levels of recommended nitrogen fertilization. The highest yields were received with the highest dose $110 \mathrm{~kg}$ $\mathrm{ha}^{-1} \mathrm{~N}$, given all at planting, followed by $80,50+30+30,50+30$ and $50 \mathrm{~kg} \mathrm{ha}^{-1} \mathrm{~N}$. The yields without fertilizer nitrogen averaged $24.8 \mathrm{t} \mathrm{ha}^{-1}$. The adjusted irrigation increased tuber yields $17 \%$. The utilization of fertilizer and organic soil nitrogen was good on potato crop if water supply was taken care of. Some values of apparent fertilizer nitrogen recovery exceeded 1.0 thus suggesting that the moderate fertilization improved the ability of potato crop to utilize the natural nitrogen sources in soils.

Key words: irrigation, nitrogen, potatoes, Solanum tuberosum, fertilizers

\section{Introduction}

A sufficient level of soil nitrogen is needed for an abundant yield growth during the tuber bulking (Burton 1989). However, high amounts of fertilizer nitrogen in planting may cause too abundant growth of the foliage in potato crop during early phases of development, and consequently delay tuber initiation and senescence of leaves (Harris 1978, Beukema and van der Zaag 1979, Allen and Scott 1980, Linnér 1988). Excessive nitrogen availability during the entire growing season, particularly near the end of tu- ber bulking, delays tuber maturity (Ojala et al. 1990).

The length of the growing season in Finnish potato production areas is only 140-180 days, and delayed tuber formation and late senescence are a risk for the yield and its quality. Therefore the application of fertilizer nitrogen must always be in a balance between potential yield and crop senescence (Varis 1972, Mustonen 1997). High amount of fertilizer nitrogen applied as a single dose at planting is an environmental risk. The nitrate nitrogen easily leaches into ground water in case of high rainfall or excessive irrigation on light, sandy soils (Harris 1978, Burton 


\section{Kuisma, P. Split nitrogen fertilization with irrigation on potato}

1989, Goffart and Guiot 1996) which are typical in potato production in Finland.

The splitting of fertilization is suggested to avoid the unfavourable effects of excessive nitrogen (Harris 1978, Burton 1989). In a split application, only a part of the total fertilizer nitrogen is given at planting, and the rest is applied later in one or several doses during the growing period.

Many studies in Western Europe have reported significant yield increase and better quality of potatoes owing to split nitrogen dressing (e.g. van Loon et al. 1987, Nitsch and Varis 1991), especially if early summers are rainy and risks to leaching are high (Linnér 1988, Goffart and Guiot 1996). Svensson et al. (1973) state that the benefits of nitrogen splitting are most obvious under the conditions where the prerequisites to growth are good and high yields are expected. The profits of split application however, are minimal if leaching is no risk (Harris 1978).

With a split application the availability of nitrogen in soil can be better matched to the crop uptake of nitrogen throughout the season. In this way, late application could be adjusted to take account of reductions in nitrogen requirement as a result of drought, frost, etc. Also higher rates of mineralization than expected can be dealt without raising the amount of residual nitrogen after harvest (Vos and Marshall 1993). According to Beukema and van der Zaag (1979) in the split fertilization the additional nitrogen should be applied not later than three weeks after the emergence.

The aim of this study was to test the effect of split application of nitrogen with adjusted irri- gation on potato yield in Finnish conditions where the recommendations of nitrogen fertilization are rather low, 40-100 kg ha-1. A partial aim was also to study if split fertilization ensured a high yield on potato in the case of rapid early development.

\section{Material and methods}

In the three year field experiment at Potato Research Institute in Lammi $\left(61^{\circ} 06^{\prime} \mathrm{N}, 23^{\circ} 02^{\prime} \mathrm{E}\right.$, $97 \mathrm{~m}$ above sea level) the irrigation and the split application of fertilizer nitrogen on potato were studied in 1993-1995. In 1993-1994, the study was done with two cultivars: Fambo, early table potato, and Tanu, early starch potato. In 1995, only a middle late crisp variety Lady Rosetta was used. The trials were located on sandy soils (Table 1) typical for potato production in Finland.

Irrigation and nitrogen fertilization were arranged in a split-plot design with three completely randomised blocks. In 1993-1994 the varieties located on two neighbouring trials. Irrigation was placed in the main plots:

$\mathrm{A}_{0}=$ unirrigated

$\mathrm{A}_{1}=$ irrigated

The irrigation was applied with nozzle boom when the soil moisture in top soil decreased to $50 \%$ of plant available water capacity (Elonen et al. 1967), determined by the gypsum block techniques (Boyoucos 1950). Gypsum blocks were installed at the depth of $30 \mathrm{~cm}$ to the mid-

Table 1. Soil properties $(0-30 \mathrm{~cm})$ on trial fields.

\begin{tabular}{lllrrrrr}
\hline Year & Soil type & $\mathrm{pH}$ & $\mathrm{Ca}$ & $\mathrm{P}$ & $\mathrm{K}$ & $\mathrm{Mg}$ & $\begin{array}{c}\text { Soil } \\
\text { inorganic N } \\
\mathrm{kg} \mathrm{ha}^{-1} \\
\text { at planting }\end{array}$ \\
\cline { 4 - 7 } & & & & & $\mathrm{mg} \mathrm{l}^{-1}$ & & \\
1993 & coarse sandy loam & 5.9 & 1050 & 12.0 & 182 & 83 & \\
1994 & fine sandy loam & 6.1 & 1210 & 7.3 & 185 & 111 & 32 \\
1995 & fine sandy loam & 5.2 & 888 & 13.0 & 162 & 63 & 25 \\
\hline
\end{tabular}


Vol. 11 (2002): 59-74.

Table 2. Dates and rates of irrigation.

\begin{tabular}{|c|c|c|c|c|c|}
\hline $\begin{array}{l}1993 \\
\text { Date }\end{array}$ & $\mathrm{mm}$ & $\begin{array}{l}1994 \\
\text { Date }\end{array}$ & $\mathrm{mm}$ & $\begin{array}{l}1995 \\
\text { Date }\end{array}$ & $\mathrm{mm}$ \\
\hline 10 June & 19 & 12-13 July & 25 & 30 June & 15 \\
\hline 16 June & 15 & 15-16 July & 30 & 18 July & 10 \\
\hline 30 June & 16 & 19 July & 12 & 2 August & 22 \\
\hline 9 July & 22 & 21-22 July & 26 & & \\
\hline 13 July & 20 & 29 July & 17 & & \\
\hline Total & 92 & & 110 & & 47 \\
\hline
\end{tabular}

dle of bed on plots of nitrogen fertilization 80 $\mathrm{kg} \mathrm{ha}^{-1}$. Dates and amount of irrigation are presented in Table 2.

The nitrogen fertilization in subplots was done with six combinations:

$\mathrm{B}_{0}=$ no nitrogen

$\mathrm{B}_{1}=$ single dose $50 \mathrm{~kg} \mathrm{ha}^{-1} \mathrm{~N}$ at planting

$\mathrm{B}_{2}=$ single dose $80 \mathrm{~kg} \mathrm{ha}^{-1} \mathrm{~N}$ at planting

$\mathrm{B}_{3}=$ single dose $110 \mathrm{~kg} \mathrm{ha}^{-1} \mathrm{~N}$ at planting

$\mathrm{B}_{4}=$ split fertilization; $50 \mathrm{~kg} \mathrm{ha}^{-1} \mathrm{~N}$ at planting,

$30 \mathrm{~kg} \mathrm{ha}^{-1} \mathrm{~N}$ at hilling

$\mathrm{B}_{5}=$ split fertilization; $50 \mathrm{~kg} \mathrm{ha}^{-1} \mathrm{~N}$ at planting,

$30 \mathrm{~kg} \mathrm{ha}^{-1} \mathrm{~N}$ at hilling, $30 \mathrm{~kg} \mathrm{ha}^{-1} \mathrm{~N}$ before blooming

At hilling, about 40 days after planting, the potato crop reached the developmental stage of 33-35 (the end of leaf expansion) (Hack et al. 1993). Second application was about 20 days later, just before blooming. In both applications fertilizers were given as top dressings.

The base nitrogen $50 \mathrm{~kg} \mathrm{ha}^{-1} \mathrm{~N}$ on split fertilization and all rates of single fertilization were placed in two rows about $5 \mathrm{~cm}$ beneath and $10 \mathrm{~cm}$ aside of seed tubers at planting with ammonium nitrate limestone (Oulunsalpietari, Kemira Agro Oy, Finland, N 27.5\%). Split applications after planting were top dressed with ammonium nitrate limestone in 1993 and with calcium nitrate (Kemira Agro Oy, Finland, N 15.5\%) in 19941995. Phosphorus and potassium were broadcast before planting as superphosphate (P 9\%) and potassium sulphate ( $\mathrm{K} 42 \%$ ), respectively, according to information of soil analysis and requirements of varieties.
At planting an individual plot consisted of four rows each $10.0 \mathrm{~m}$ long and $80 \mathrm{~cm}$ apart. Potato yields were quantified by harvesting two middle rows of $8.0 \mathrm{~m}$ length from each plot. A trial field was ploughed to the depth of $25 \mathrm{~cm}$ in the previous autumn after the harvest of spring barley. A day before planting, the seed bed was tilled twice with a spring-tined harrow to the depth of $17 \mathrm{~cm}$. Seed presprouted for three weeks in light, was planted to the depth of $5 \mathrm{~cm}$ with a semiautomatic two-row planter on 12 May, 18 May and 5 June in 1993, 1994 and 1995, respectively. The planting distance was $31 \mathrm{~cm}$ on both varieties in 1993. In 1994 Fambo was planted to $31 \mathrm{~cm}$ and Tanu to $26 \mathrm{~cm}$. In 1995 Lady Rosetta was planted to $28 \mathrm{~cm}$. The size of certified seed (class A) was 30-45 mm, 35-50 mm and 30-40 mm in 1993, 1994 and 1995, respectively. Trials were earthed about 40 days after planting with a two-row mouldboard ridger. Plant protection was done according to the local agricultural practice. Trials were harvested with a tractor carried onerow harvester on 28 August, 6-7 September and 13 September in 1993, 1994 and 1995, respectively.

Crop analysis during growing season included observations of emergence time, occurrence of crop diseases and determinations of growth stage on 45, 75 and 90 days after planting (DAP) using a modification of the growth stage identification keys described by Hack et al. (1993). After the harvest, yields were graded into tuber sizes on $10 \mathrm{~mm}$ differences which were summarized as size distribution $30-40 \mathrm{~mm}, 40-70 \mathrm{~mm}$, and $>70 \mathrm{~mm}$. Before grading a sample of about 


\section{Kuisma, P. Split nitrogen fertilization with irrigation on potato}

Table 3. Weather conditions at Potato Research Institute in 1993-1995 and 30-year averages at Helsinki University, Lammi Biological Research Station.

\begin{tabular}{|c|c|c|c|c|c|c|c|c|}
\hline \multirow[b]{2}{*}{ Month } & \multicolumn{4}{|c|}{ Mean temperature $\left({ }^{\circ} \mathrm{C}\right)$} & \multicolumn{4}{|c|}{ Precipitation (mm) } \\
\hline & 1993 & 1994 & 1995 & 1961-1990 & 1993 & 1994 & 1995 & 1961-1990 \\
\hline May & 12.6 & 7.6 & 7.2 & 8.8 & 3 & 41 & 98 & 38 \\
\hline June & 11.0 & 12.2 & 15.6 & 14.0 & 58 & 60 & 28 & 47 \\
\hline July & 14.8 & 19.0 & 13.5 & 16.7 & 118 & 4 & 56 & 74 \\
\hline August & 12.0 & 14.3 & 13.3 & 14.8 & 129 & 70 & 63 & 87 \\
\hline September & 4.8 & 9.4 & 7.8 & 9.7 & 32 & 105 & 43 & 68 \\
\hline Mean/Sum & 11.1 & 12.5 & 11.5 & 12.8 & 340 & 280 & 288 & 314 \\
\hline $\mathrm{DD}^{\circ} \mathrm{C}^{1)}$ & 967 & 1160 & 914 & & & & & \\
\hline
\end{tabular}

${ }^{1)} \mathrm{DD}{ }^{\circ} \mathrm{C}=$ effective temperature $\operatorname{sum}\left(>+5^{\circ} \mathrm{C}\right)$

$5 \mathrm{~kg}$ tubers per plot was taken for specific gravity determinations and for analysis of external quality. Specific gravity was converted to starch content according to the table used on official variety trials (Kangas 1998). After the determination of specific gravity samples, treatments were joined over replicates for analysis of external quality and in 1994-1995 also for analysis of total nitrogen content in tubers. Thus the differences between means of these analyses were not studied statistically.

Classification of tuber defects described by Kangas (1998) was used in analysis of external quality. Marketable yield on cultivars Fambo and Lady Rosetta was determined as a yield of 40$70 \mathrm{~mm}$ sized healthy tubers. The total nitrogen content of tubers at final harvest was analysed in a commercial laboratory (Novalab Oy) with the Kjeldahl method, the sample being 20 medium size tubers. The nitrate nitrogen content was analysed from 20 middle size tubers at Potato Research Institute using ion specific electrodes according to VTT Method 4207-84 described detailed by Ruippo and Alikärri (1989).

In 1994-1995 the soil inorganic nitrogen $\left(\mathrm{NO}_{3}{ }^{-} \mathrm{N}\right.$ and $\left.\mathrm{NH}_{4}{ }^{+}-\mathrm{N}\right)$ before planting, weekly during the growing period between 40-75 DAP and after harvest were determined using the "soil baggage", developed by Kemira Agro Oy (1994). Before the planting one sample consisted of twenty sub samples from the depth of $0-30 \mathrm{~cm}$, taken randomly on the trial field before the tillage. After the harvest, samples consisted of five sub samples on every plot from the depth of 0 $30 \mathrm{~cm}$. At 40, 47, 54, 61, 68 and 75 DAP the samples were collected as two whole bed profiles on every plot.

Weather in May-September (Table 3) was measured at Potato Research Institute. The long term averages were taken from the Finnish Meteorological Institute's weather station at Helsinki University, Lammi Biological Station, located $4 \mathrm{~km}$ from the experiments.

The data were collected and calculated on a MS ${ }^{\circledR}$ Excel-Worksheet. The results were further analyzed with a SPSS 10.01 -statistical package using the analysis of variance by split-plot design on GLM-procedure where years, and varieties in trials 1993-1994 were analyzed as fixed factors in series of experiments:

$$
\begin{aligned}
Y_{i j k l m}= & \mu+T_{j}+V_{k}+T V_{j k}+e_{i j}^{(1)}+I_{l}+T I_{j l}+V I_{k l} \\
& +T V I_{j k l}+e_{i j k l}(2)+N_{m}+T N_{j m}+V N_{k m} \\
& +T V N_{j k m}+I N_{l m}+T I N_{j l m}+V I N_{k l m} \\
& +T V I N_{j k l m}+e_{i j k l m}^{(3)}
\end{aligned}
$$

where $Y_{i j k l m}$ is the response for the block i, trial year $\mathrm{j}$, variety $\mathrm{k}$, irrigation 1 and nitrogen fertilization $\mathrm{m} ; \mu$ is the overall mean; $\mathrm{B}$ is the random block effect; T, V, I and $\mathrm{N}$ are the fixed effects of trial year, variety, irrigation and nitrogen fertilization; TV, ...,TVIN interactions of fixed effects; and the random error terms eijk $k^{(1)}=$ 
Vol. 11 (2002): 59-74.

Table 4. Summaries of variance analysis on varieties Fambo and Tanu in 1993-1994.

\begin{tabular}{|c|c|c|c|c|c|c|c|c|c|c|}
\hline $\begin{array}{l}\text { Source of } \\
\text { variation }\end{array}$ & Emergence & DAP45 & DAP75 & DAP90 & $\begin{array}{l}\text { Tuber } \\
\text { yield }\end{array}$ & Starch-\% & $\begin{array}{c}\text { Starch } \\
\text { yield }\end{array}$ & $<40 \mathrm{~mm}$ & $40-70 \mathrm{~mm}$ & $>70 \mathrm{~mm}$ \\
\hline Year (Y) & $* * *$ & $* * *$ & $* * *$ & $* * *$ & $*$ & Ns & $* * *$ & $* * *$ & $* * *$ & $* * *$ \\
\hline Variety (V) & $*$ & Ns & Ns & $* * *$ & $* * *$ & $* * *$ & Ns & $* * *$ & $* * *$ & Ns \\
\hline $\mathrm{YxV}$ & $*$ & $*$ & $*$ & Ns & Ns & $\circ$ & Ns & $* * *$ & $* * *$ & $*$ \\
\hline Irrigation (I) & $*$ & Ns & $\circ$ & $*$ & $* * *$ & $\circ$ & $* * *$ & $* * *$ & $* * *$ & Ns \\
\hline YxI & $*$ & $*$ & $\circ$ & $* * *$ & $* * *$ & $\circ$ & $* * *$ & $* * *$ & $* * *$ & Ns \\
\hline VxI & Ns & Ns & $* *$ & $*$ & Ns & Ns & Ns & $* *$ & $* * *$ & $\circ$ \\
\hline YxVxI & $\circ$ & Ns & Ns & $*$ & Ns & Ns & Ns & $* *$ & $* *$ & Ns \\
\hline Nitrogen $(\mathrm{N})$ & $* * *$ & $* * *$ & $* * *$ & $* * *$ & $* * *$ & $* * *$ & $* * *$ & $* * *$ & $* * *$ & $* * *$ \\
\hline $\mathrm{YxN}$ & $* * *$ & $* * *$ & $*$ & Ns & $* * *$ & $*$ & $* * *$ & $* *$ & $* * *$ & Ns \\
\hline $\mathrm{VxN}$ & Ns & $*$ & Ns & $* *$ & $\circ$ & $*$ & $* *$ & $* *$ & Ns & Ns \\
\hline $\mathrm{IxN}$ & $*$ & Ns & $\mathrm{Ns}$ & $*$ & Ns & $* * *$ & Ns & $*$ & $*$ & Ns \\
\hline $\mathrm{YxVxN}$ & $*$ & Ns & Ns & Ns & $* *$ & Ns & $*$ & $* * *$ & $* *$ & $*$ \\
\hline YxIxN & Ns & Ns & Ns & Ns & $* * *$ & Ns & $* *$ & $*$ & $* *$ & Ns \\
\hline VxIxN & Ns & Ns & $\mathrm{Ns}$ & $\mathrm{Ns}$ & $\mathrm{Ns}$ & Ns & $\mathrm{Ns}$ & $*$ & $* *$ & Ns \\
\hline YxVxIxN & $\circ$ & Ns & Ns & Ns & Ns & Ns & Ns & $*$ & Ns & Ns \\
\hline
\end{tabular}

$\mathrm{DAP}=$ days after planting; $\mathrm{Ns}=$ no significant difference ${ }^{\circ}=0.1<\mathrm{P}<0.05 ; *=0.05<\mathrm{P}<0.01 ; * *=0.01<\mathrm{P}<0.001$; $* * *=\mathrm{P}<0.001$

Table 5. Summaries of variance analysis on variety Lady Rosetta in 1995.

\begin{tabular}{lcccccccccc}
\hline $\begin{array}{l}\text { Source of } \\
\text { variation }\end{array}$ & Emergence DAP45 & DAP75 & DAP90 & $\begin{array}{c}\text { Tuber } \\
\text { yield }\end{array}$ & $\begin{array}{l}\text { Starch- } \% \\
\text { Starch } \\
\text { yield }\end{array}$ & $<40 \mathrm{~mm}$ & $40-70 \mathrm{~mm}>70 \mathrm{~mm}$ \\
\hline $\begin{array}{l}\text { Irrigation (I) } \\
\text { Nitrogen (N) }\end{array}$ & $\mathrm{Ns}$ & $\mathrm{Ns}$ & $\mathrm{Ns}$ & $\mathrm{Ns}$ & $\mathrm{Ns}$ & $\mathrm{Ns}$ & $\mathrm{Ns}$ & $\mathrm{Ns}$ & $\mathrm{Ns}$ & $* *$ \\
IxN & $\mathrm{Ns}$ & $\mathrm{Ns}$ & $\mathrm{Ns}$ & $*$ & $* * *$ & $* * *$ & $* * *$ & $\mathrm{Ns}$ & $\mathrm{N}$ & $\mathrm{Ns}$ \\
\hline
\end{tabular}

$\mathrm{DAP}=$ days after planting; $\mathrm{Ns}=$ no significant difference ${ }^{\circ}=0.1<\mathrm{P}<0.05 ; *=0.05<\mathrm{P}<0.01 ; * *=0.01<\mathrm{P}<0.001$; $* * *=\mathrm{P}<0.0$

$\mathrm{T}(\mathrm{V}(\mathrm{B})), \quad e_{i j k l}^{(2)}=\mathrm{T}(\mathrm{V}(\mathrm{IB}))$ and $e_{i j k l m}^{(3)}=$ $\mathrm{T}(\mathrm{V}(\mathrm{I}(\mathrm{NB})))$ (Snedecor 1956).

In 1995 the analysis of variance was based on the following mixed model for split-plot design:

$Y_{i l m}=\mu+B_{i}+I_{l}+e_{i l}^{(1)}+N_{m}+I N_{l m}+e_{i l m}^{(2)}$

where $Y_{i l m}$ is the response for the block i, irrigation 1 and nitrogen fertilization $\mathrm{m} ; \mu$ is the overall mean; $\mathrm{B}$ is the random block effect; I and $\mathrm{N}$ are the fixed effects of irrigation and nitrogen fertilization; IN is the two-factor interaction of fixed effects; and the random error terms $e_{i l}^{(1)}=$ $\mathrm{BI}$ and $e_{i l m}{ }^{(2)}=\mathrm{I}(\mathrm{NB})$. Summaries of variance analysis are presented in Tables 4 and 5. The sta- tistical differences $(\mathrm{P}<0.05)$ between group means were further studied by Tukey's HSD (Honestly Significant Difference) test.

\section{Results and discussion}

\section{Crop development}

On the emergence, the greatest differences were between years and varieties, as expected. May 1993 was exceptionally warm, and potatoes planted in the middle of May emerged in two 


\section{Kuisma, P. Split nitrogen fertilization with irrigation on potato}

Table 6. Crop development in 1993-1994.

\begin{tabular}{|c|c|c|c|c|c|c|c|c|}
\hline \multirow[t]{2}{*}{ Year } & \multirow[t]{2}{*}{ Variety } & \multirow{2}{*}{$\begin{array}{l}\text { Fertilization } \\
\mathrm{kg} / \mathrm{ha} \mathrm{N}\end{array}$} & \multicolumn{2}{|c|}{45 DAP } & \multicolumn{2}{|c|}{75 DAP } & \multicolumn{2}{|c|}{90 DAP } \\
\hline & & & $\mathrm{U}$ & I & $\mathrm{U}$ & I & $\mathrm{U}$ & I \\
\hline \multirow[t]{14}{*}{1993} & Fambo & 0 & $36^{\mathrm{a}}$ & $36^{\mathrm{a}}$ & $77^{\mathrm{a}}$ & $75^{\mathrm{abc}}$ & $81^{\mathrm{a}}$ & $83^{a b}$ \\
\hline & & 50 & $36^{\mathrm{a}}$ & $36^{\mathrm{a}}$ & $81^{\mathrm{a}}$ & $81^{\mathrm{a}}$ & $83^{\mathrm{a}}$ & $84^{\mathrm{a}}$ \\
\hline & & 80 & $37^{\mathrm{a}}$ & $36^{\mathrm{a}}$ & $78^{\mathrm{a}}$ & $78^{\mathrm{ab}}$ & $82^{\mathrm{a}}$ & $84^{\mathrm{a}}$ \\
\hline & & 110 & $36^{\mathrm{a}}$ & $36^{\mathrm{a}}$ & $78^{\mathrm{a}}$ & $71^{\mathrm{c}}$ & $82^{\mathrm{a}}$ & $81^{\mathrm{b}}$ \\
\hline & & $50+30$ & $35^{\mathrm{a}}$ & $36^{\mathrm{a}}$ & $81^{\mathrm{a}}$ & $81^{\mathrm{a}}$ & $83^{\mathrm{a}}$ & $84^{a}$ \\
\hline & & $50+30+30$ & $36^{\mathrm{a}}$ & $35^{\mathrm{a}}$ & $81^{\mathrm{a}}$ & $74^{\mathrm{bc}}$ & $82^{\mathrm{a}}$ & $82^{\mathrm{ab}}$ \\
\hline & & Mean & $36^{\mathrm{A}}$ & $36^{\mathrm{A}}$ & $79^{\mathrm{A}}$ & $77^{\mathrm{B}}$ & $82^{\mathrm{A}}$ & $83^{\mathrm{A}}$ \\
\hline & Tanu & 0 & $34^{\mathrm{a}}$ & $34^{\mathrm{a}}$ & $74^{\mathrm{a}}$ & $74^{\mathrm{ab}}$ & $78^{\mathrm{b}}$ & $78^{c}$ \\
\hline & & 50 & $33^{\mathrm{a}}$ & $34^{\mathrm{a}}$ & $74^{\mathrm{a}}$ & $78^{\mathrm{a}}$ & $82^{\mathrm{a}}$ & $84^{\mathrm{a}}$ \\
\hline & & 80 & $34^{\mathrm{a}}$ & $35^{\mathrm{a}}$ & $71^{\mathrm{a}}$ & $78^{a}$ & $81^{\mathrm{a}}$ & $83^{\mathrm{ab}}$ \\
\hline & & 110 & $35^{\mathrm{a}}$ & $36^{\mathrm{a}}$ & $71^{\mathrm{a}}$ & $71^{\mathrm{b}}$ & $81^{\mathrm{a}}$ & $81^{\mathrm{b}}$ \\
\hline & & $50+30$ & $34^{\mathrm{a}}$ & $34^{\mathrm{a}}$ & $74^{\mathrm{a}}$ & $78^{\mathrm{a}}$ & $82^{\mathrm{a}}$ & $83^{\mathrm{ab}}$ \\
\hline & & $50+30+30$ & $33^{\mathrm{a}}$ & $35^{\mathrm{a}}$ & $74^{\mathrm{a}}$ & $77^{\mathrm{ab}}$ & $81^{\mathrm{a}}$ & $81^{\mathrm{b}}$ \\
\hline & & Mean & $34^{\mathrm{A}}$ & $35^{\mathrm{A}}$ & $73^{\mathrm{B}}$ & $76^{\mathrm{A}}$ & $81^{\mathrm{A}}$ & $82^{\mathrm{A}}$ \\
\hline \multirow[t]{14}{*}{1994} & Fambo & 0 & $25^{\mathrm{c}}$ & $26^{\mathrm{b}}$ & $72^{\mathrm{a}}$ & $71^{\mathrm{a}}$ & $82^{\mathrm{a}}$ & $81^{\mathrm{a}}$ \\
\hline & & 50 & $30^{\mathrm{a}}$ & $29^{a}$ & $74^{\mathrm{a}}$ & $72^{\mathrm{a}}$ & $84^{\mathrm{a}}$ & $81^{\mathrm{a}}$ \\
\hline & & 80 & $27^{\mathrm{bc}}$ & $27^{\mathrm{ab}}$ & $73^{\mathrm{a}}$ & $72^{\mathrm{a}}$ & $82^{\mathrm{a}}$ & $81^{\mathrm{a}}$ \\
\hline & & 110 & $28^{\mathrm{ab}}$ & $28^{\mathrm{ab}}$ & $72^{\mathrm{a}}$ & $72^{\mathrm{a}}$ & $82^{\mathrm{a}}$ & $81^{\mathrm{a}}$ \\
\hline & & $50+30$ & $28^{\mathrm{ab}}$ & $29^{\mathrm{a}}$ & $72^{\mathrm{a}}$ & $72^{\mathrm{a}}$ & $84^{\mathrm{a}}$ & $82^{\mathrm{a}}$ \\
\hline & & $50+30+30$ & $30^{\mathrm{a}}$ & $29^{a}$ & $73^{a}$ & $72^{\mathrm{a}}$ & $83^{\mathrm{a}}$ & $81^{\mathrm{a}}$ \\
\hline & & Mean & $28^{\mathrm{A}}$ & $28^{\mathrm{A}}$ & $73^{\mathrm{A}}$ & $72^{\mathrm{A}}$ & $82^{\mathrm{A}}$ & $81^{\mathrm{A}}$ \\
\hline & Tanu & 0 & $26^{\mathrm{b}}$ & $25^{\mathrm{c}}$ & $74^{\mathrm{a}}$ & $72^{\mathrm{a}}$ & $82^{\mathrm{a}}$ & $77^{\mathrm{bc}}$ \\
\hline & & 50 & $30^{\mathrm{a}}$ & $30^{\mathrm{ab}}$ & $76^{\mathrm{a}}$ & $73^{a}$ & $84^{\mathrm{a}}$ & $81^{\mathrm{a}}$ \\
\hline & & 80 & $30^{\mathrm{a}}$ & $28^{\mathrm{b}}$ & $75^{\mathrm{a}}$ & $72^{\mathrm{a}}$ & $82^{\mathrm{a}}$ & $77^{\mathrm{bc}}$ \\
\hline & & 110 & $30^{\mathrm{a}}$ & $30^{\mathrm{ab}}$ & $75^{\mathrm{a}}$ & $71^{\mathrm{a}}$ & $82^{\mathrm{a}}$ & $74^{\mathrm{d}}$ \\
\hline & & $50+30$ & $30^{\mathrm{a}}$ & $31^{\mathrm{a}}$ & $75^{\mathrm{a}}$ & $72^{\mathrm{a}}$ & $84^{\mathrm{a}}$ & $79^{\mathrm{ab}}$ \\
\hline & & $50+30+30$ & $31^{\mathrm{a}}$ & $31^{\mathrm{a}}$ & $75^{\mathrm{a}}$ & $72^{\mathrm{a}}$ & $83^{\mathrm{a}}$ & $75^{\mathrm{cd}}$ \\
\hline & & Mean & $30^{\mathrm{A}}$ & $29^{\mathrm{A}}$ & $75^{\mathrm{A}}$ & $72^{\mathrm{B}}$ & $83^{\mathrm{A}}$ & $77^{\mathrm{B}}$ \\
\hline
\end{tabular}

DAP = days after planting; $\mathrm{U}=$ unirrigated; $\mathrm{I}=$ irrigated

Within a single column group means followed by the same letter (with capital letters between irrigation treatments in each DAP) are not statistically different at level $\mathrm{P}<0.05$ in Tukey's HSD-test.

and a half weeks. May 1994 was cooler than the average, and the emergence required about one month. In 1995 the trial was planted at the beginning of June, and variety Lady Rosetta emerged about five days faster than Fambo and Tanu in 1993. The development of crop followed the order of emergence in the early growth (45 DAP). In 1995, the faster growth of Lady Rosetta continued to the harvest (Table 6).
In 1993 the main plots of irrigation emerged about 0.9 days faster than unirrigated plots. The difference was statistically significant $(\mathrm{P}<0.05)$ although it had no practical meaning. Nitrogen fertilisation, interacted with year $(\mathrm{P}<0.001)$, irrigation $(\mathrm{P}<0.05)$ and year $x$ variety $(\mathrm{P}<0.05)$, also had highly significant influence $(\mathrm{P}<0.001)$ on the emergence, the influence, however, having again no practical meaning. 
The effect of irrigation on the development of the canopy was seen in 1994 when the irrigation significantly $(\mathrm{P}<0.001)$ delayed the growth from 75 DAP, especially on cultivar Tanu. In 1994 the last irrigation was given near the end of July. Ojala et al. (1990) reported that irrigation can slightly delay the maturity of potato crop if applied abundantly in the latter part of the growing season.

The effects of nitrogen fertilization varied during the growing period and were dependent on year and variety. On Lady Rosetta in 1995, the only significant difference $(\mathrm{P}<0.05)$, although practically meaningless, was detected at 90 DAP on the development of potato canopy due to nitrogen fertilization. On cultivars Fambo and Tanu in 1993-1994 at early growth (45 DAP), when the only differences between nitrogen fertilization were from planting and no irrigation was yet given, unfertilized potatoes grew significantly $(\mathrm{P}<0.001)$ slower, other nitrogen rates being similar. The slow development of unfertilized potato continued to the harvest. The unfavourable effect of high nitrogen rate in planting and the late split application came out during the summer, and was most visible at 75 DAP in 1993. Similar results were published by e.g. Harris (1978). The interaction between irrigation and nitrogen fertilization on the development of potato canopy was weak as Harris (1990) reported.

\section{Yield}

The results of this study showed that the split application of nitrogen compared to a single dose at planting did not give any additional advantages on yield, size distribution, starch content or external quality in Finnish conditions when moderate nitrogen rates were used (Figs. 1 and 2 ). The highest yields were produced when the highest rate $110 \mathrm{~kg} \mathrm{ha}^{-1} \mathrm{~N}$ was given at planting. The same amount of nitrogen split into three applications resulted to about the same yield as $80 \mathrm{~kg} \mathrm{ha}^{-1} \mathrm{~N}$ in a single dose, and $80 \mathrm{~kg} \mathrm{ha}^{-1} \mathrm{~N}$ split into two applications gave the yield com- parable to a single dose of $50 \mathrm{~kg} \mathrm{ha}^{-1} \mathrm{~N}$. However, the yield decrease due to split fertilization was clearly smaller than noticed in earlier studies in 1980s at Potato Research Institute (Perunantutkimuslaitos 1985). In Michigan, USA, Joern and Vitosh (1995a) made the same conclusion when studying the similar levels of nitrogen fertilization for Russet Burbank potatoes under the similar length of growing season as in Finland. Neither in conditions of Alaska, did the split fertilization influence the potato yield (Gavlak et al. 1993). Similarly e.g. Svensson et al. (1973), Carlsson (1977, 1988, 1995) and Goffart and Guiot (1996) report that the split application of fertilizer nitrogen does not differ from the fertilization where all nitrogen is given at planting when moderate rates of nitrogen are used. In Middle Sweden, Carlsson (1995) noticed yield decrease even up to $30 \%$ due to split application of nitrogen fertilization compared to a placement of all fertilizers at planting.

Van Loon et al. (1987) in Holland noticed at the end of eighties that a split application was advantageous only when the total rates of fertilizer nitrogen were high (> $\left.200 \mathrm{~kg} \mathrm{ha}^{-1} \mathrm{~N}\right)$. Sieczka et al. (1993) reported that there was no response to supplemental nitrogen during the growing period when $\geq 168 \mathrm{~kg} \mathrm{ha}^{-1} \mathrm{~N}$ was given at planting. MacLean (1984) in Atlantic Canada also noticed that no yield increase was reached if the nitrogen rate exceeded $135 \mathrm{~kg} \mathrm{ha}^{-1}$, and the split application didn't change the situation. In this study the highest rate of fertilizer nitrogen was clearly smaller, only $110 \mathrm{~kg} \mathrm{ha}^{-1} \mathrm{~N}$, than in the studies mentioned.

The irrigation affected significantly ( $\mathrm{P}<$ 0.001) the tuber yield in 1993-1994 on cultivars Fambo and Tanu (Table 4). The influence was, however, dependent on the year. In 1993, July and August were rainy and cool, but in 1994 July was extremely dry and hot. Consequently all yield increase due to irrigation was acquired in 1994 when the increase of tuber yield on irrigated plots was $42 \%$ (Table 7). In 1995, June and July were slightly drier, but clearly cooler than normally and irrigation had no effect on the tuber yield of variety Lady Rosetta. The signifi- 


\section{AGRICULTURAL AND FOOD SCIENCE IN FINLAND}

Kuisma, P. Split nitrogen fertilization with irrigation on potato
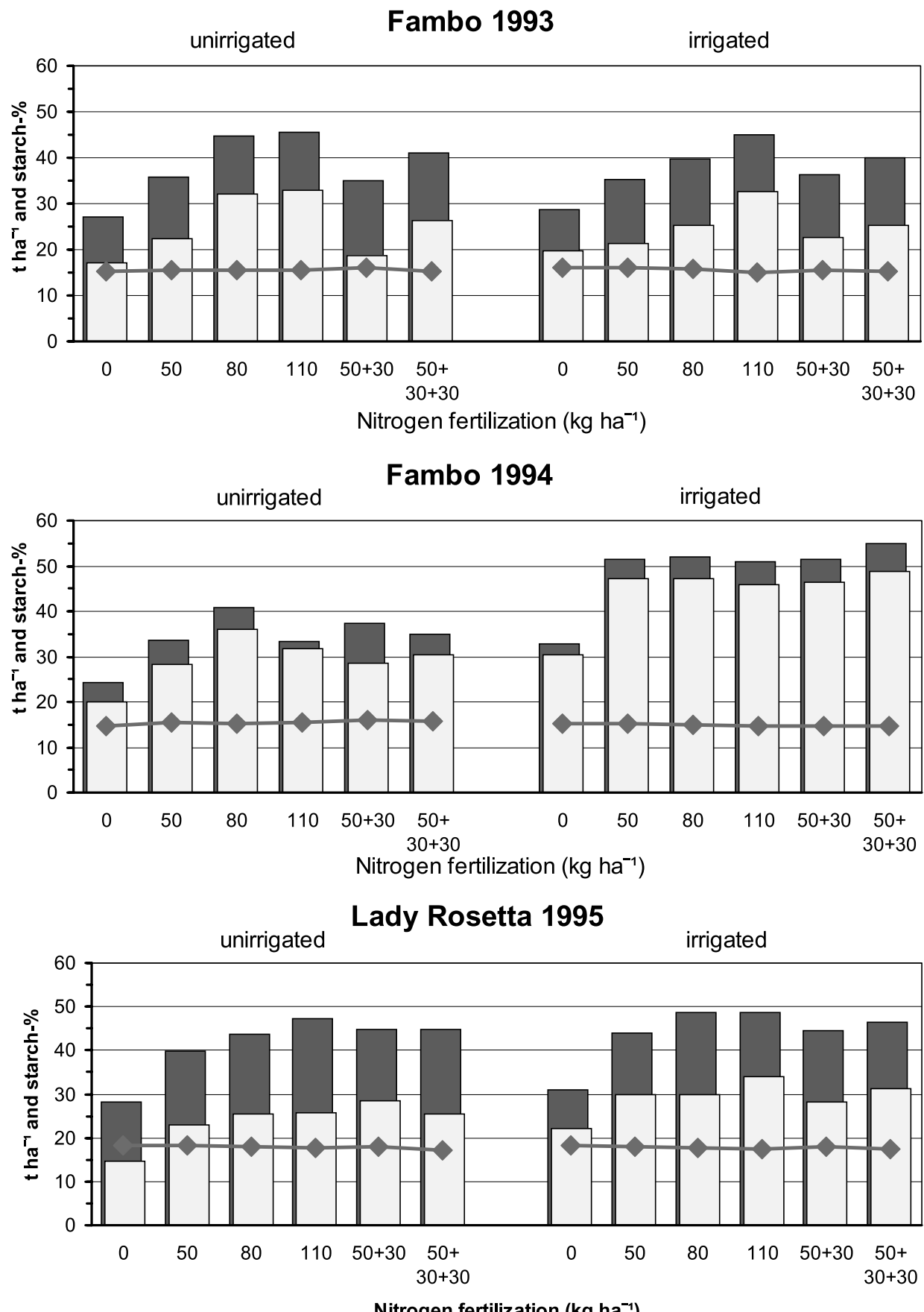

Nitrogen fertilization (kg ha $\left.{ }^{-1}\right)$

$\square$ Total yield $\square$ Marketable yield $40-70 \mathrm{~mm} \leadsto$ Starch-\%

Fig. 1. Effects of irrigation and nitrogen fertilization on yields and starch content of varieties Fambo in 1993-1994 and Lady Rosetta in 1995. 


\section{AGRICULTURAL AND FOOD SCIENCE IN FINLAND}

Vol. 11 (2002): 59-74.
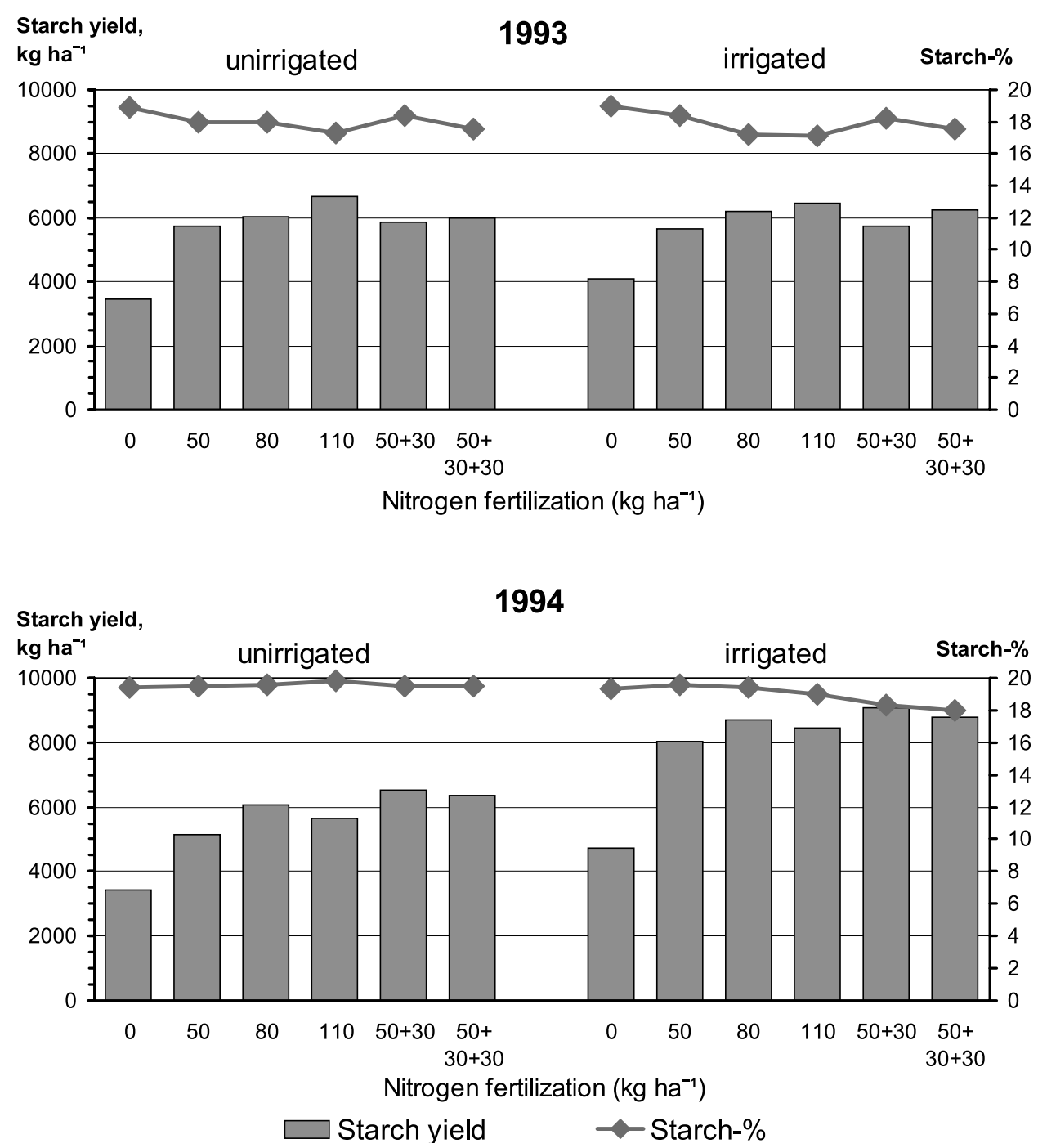

Fig. 2. Effects of irrigation and nitrogen fertilization on starch production of variety Tanu in 1993-1994.

cant interaction of irrigation and nitrogen fertilization was seen in the way that differences between fertilized plots were smaller compared to the unirrigated crop (Figs. 1 and 2). Especially yields on split fertilization approached yields produced with the same amount of nitrogen as in a single dose at planting. Similar results are reported by e.g. Guarda et al. (1990, 1993, 1996).

Compared to the tuber yields the variation was much smaller on starch content or external quality of tubers. Consequently starch yields and marketable $40-70 \mathrm{~mm}$ yields were most related to total tuber yield (Figs. 1 and 2). As expected the highest rates of fertilizer nitrogen produced lower starch content. The effect was stronger on irrigated potato and nearly same wether a single dose or a split application was used. Carlsson (1977) and Walther (1984) reported that the split application of nitrogen had influence on neither the starch nor dry matter content of tubers.

The irrigation had no influence on starch content. Ojala et al. (1990) also summarized that 


\section{Kuisma, P. Split nitrogen fertilization with irrigation on potato}

Table 7. Effects of irrigation on tuber yield, size distribution and external quality in 1993-1995.

\begin{tabular}{|c|c|c|c|c|c|c|c|c|c|c|}
\hline \multirow[b]{2}{*}{ Year } & \multirow[b]{2}{*}{ Variety } & \multirow[b]{2}{*}{ Irrigation } & \multirow{2}{*}{$\begin{array}{l}\text { Tuber yield } \\
\qquad \mathrm{t} \mathrm{ha}^{-1}\end{array}$} & \multicolumn{3}{|c|}{ Tuber size (mm) } & \multicolumn{4}{|c|}{$\%$ of tubers } \\
\hline & & & & $<40$ & $40-70$ & $>70$ & Healthy & Scab & $\begin{array}{l}\text { Shape } \\
\text { defects }\end{array}$ & Green \\
\hline \multirow[t]{4}{*}{1993} & Fambo & Unirrigated & $38.2^{\mathrm{a}}$ & $11^{\mathrm{a}}$ & $87^{\mathrm{a}}$ & $2^{\mathrm{a}}$ & 64 & 16 & 4 & 8 \\
\hline & & Irrigated & $37.4^{\mathrm{a}}$ & $13^{\mathrm{a}}$ & $84^{\mathrm{a}}$ & $3^{\mathrm{a}}$ & 65 & 8 & 2 & 11 \\
\hline & Tanu & Unirrigated & $31.4^{\mathrm{a}}$ & $18^{\mathrm{a}}$ & $78^{\mathrm{a}}$ & $4^{a}$ & 48 & 29 & 11 & 6 \\
\hline & & Irrigated & $32.2^{\mathrm{a}}$ & $19^{\mathrm{a}}$ & $77^{\mathrm{a}}$ & $3^{\mathrm{a}}$ & 63 & 8 & 6 & 5 \\
\hline \multirow[t]{4}{*}{1994} & Fambo & Unirrigated & $34.0^{\mathrm{b}}$ & $13^{\mathrm{a}}$ & $85^{\mathrm{b}}$ & $2^{\mathrm{a}}$ & 81 & 0 & 0 & 2 \\
\hline & & Irrigated & $48.9^{\mathrm{a}}$ & $6^{\mathrm{b}}$ & $91^{\mathrm{a}}$ & $3^{a}$ & 82 & 0 & 0 & 2 \\
\hline & Tanu & Unirrigated & $28.2^{\mathrm{b}}$ & $61^{\mathrm{a}}$ & $39^{b}$ & $0^{\mathrm{a}}$ & 89 & 0 & 0 & 1 \\
\hline & & Irrigated & $42.2^{\mathrm{a}}$ & $35^{\mathrm{b}}$ & $65^{\mathrm{a}}$ & $0^{\mathrm{a}}$ & 85 & 2 & 0 & 2 \\
\hline \multirow[t]{2}{*}{1995} & Lady Rosetta & Unirrigated & $41.5^{\mathrm{a}}$ & $9^{a}$ & $90^{\mathrm{a}}$ & $1^{\mathrm{a}}$ & 42 & 4 & 2 & 2 \\
\hline & & Irrigated & $43.8^{\mathrm{a}}$ & $8^{a}$ & $90^{\mathrm{a}}$ & $2^{\mathrm{a}}$ & 54 & 2 & 1 & 2 \\
\hline
\end{tabular}

Within a single column group, means followed by the same letter are not statistically different at level P $<0.05$ in Tukey's HSD-test

irrigation didn't necessary decrease the starch content of potato. At Potato Research Institute in 1989-1991, the irrigation even increased the starch content of potato in years with dry early summers and early start of irrigation (Kuisma 1998).

Due to small and irregular, although statistically significant differences caused by a larger portion of small tubers $(<40 \mathrm{~mm})$ on unfertilized potatoes, tuber size distribution and external quality are worth examining only in relation to irrigation. The effect of irrigation on tuber size distribution was strongly affected by the trial year. In 1993 and 1995 the irrigation had no effect on tuber size. In the dry summer of 1994 , the irrigation increased the proportion of tubers 40-70 $\mathrm{mm}$ at the expense of those of a small size $<40 \mathrm{~mm}$ on variety Tanu. On variety Fambo the influence of irrigation on tuber size was similar but clearly smaller than on variety Tanu (Table 7).

On the average, the variation on quality defects due to fertilization was small and uneven for any conclusions. Thus they are ignored in further examination. The studies in Norway have shown that split application of nitrogen has no effect on the external quality of tubers (Hveem fors $\emptyset$ ksgard 1991). Hunnius et al. (1972) also noticed that the split application of fertilizer nitrogen didn't affect tuber defects.

The clearest influence of irrigation was seen on common scab. Irrigation decreased the proportion of scabby tubers by $60 \%$ in 1993 when June was very dry. Tuber shape was also slightly better on irrigated crop (Table 7).

\section{Nitrogen balance}

Soil nitrogen mineralisation is approximately $50 \mathrm{~kg} \mathrm{ha}^{-1}$ annually in southern Finland (Linden et al. 1992). In this study soil inorganic nitrogen in 0-30 cm layer before planting was $25 \mathrm{~kg} \mathrm{ha}^{-1}$ $\mathrm{N}$ and $32 \mathrm{~kg} \mathrm{ha}^{-1} \mathrm{~N}$ in 1994 and 1995, respectively. Values are on the level reported in Finland by Leppänen and Esala (1995).

In the dry summer of 1994, soil inorganic nitrogen fluctuated independently of variety, water supply or even of supply of fertilizer nitrogen up to middle of July (Fig. 3). The highest values were unreliable because the analysis method was no more accurate when soil inorganic nitrogen exceeded ca. $150 \mathrm{~kg} \mathrm{ha}^{-1} \mathrm{~N}$. From the latter part of July the effects of drought could 
Vol. 11 (2002): 59-74.

\section{Fambo}
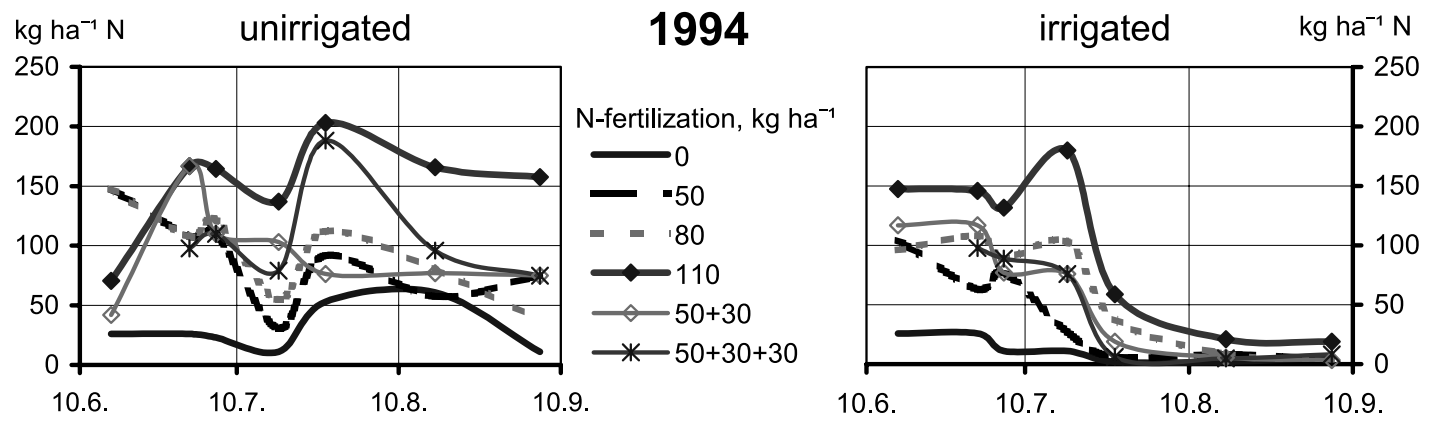

\section{Tanu}
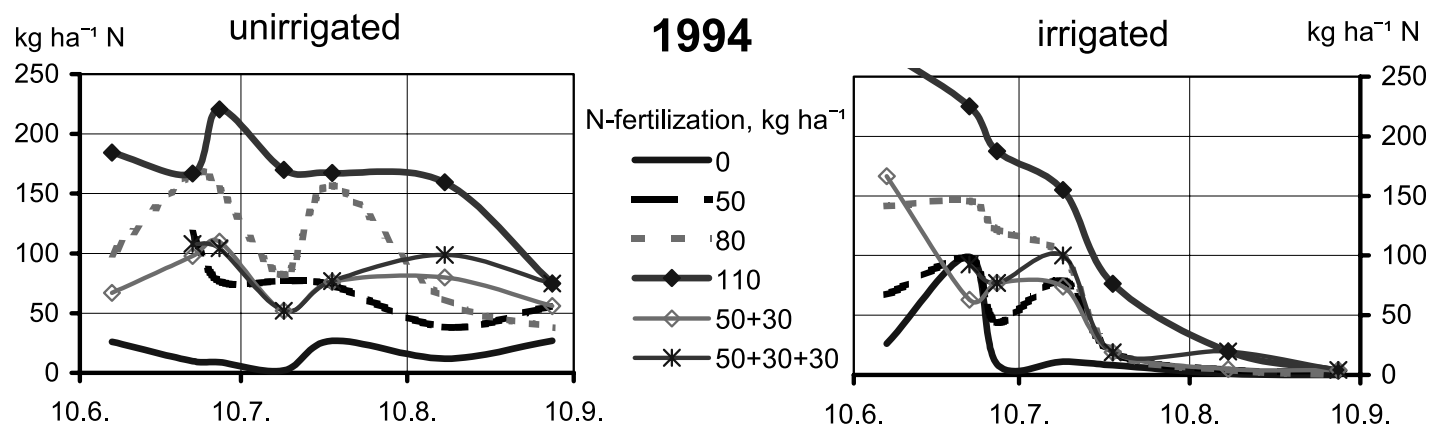

Lady Rosetta

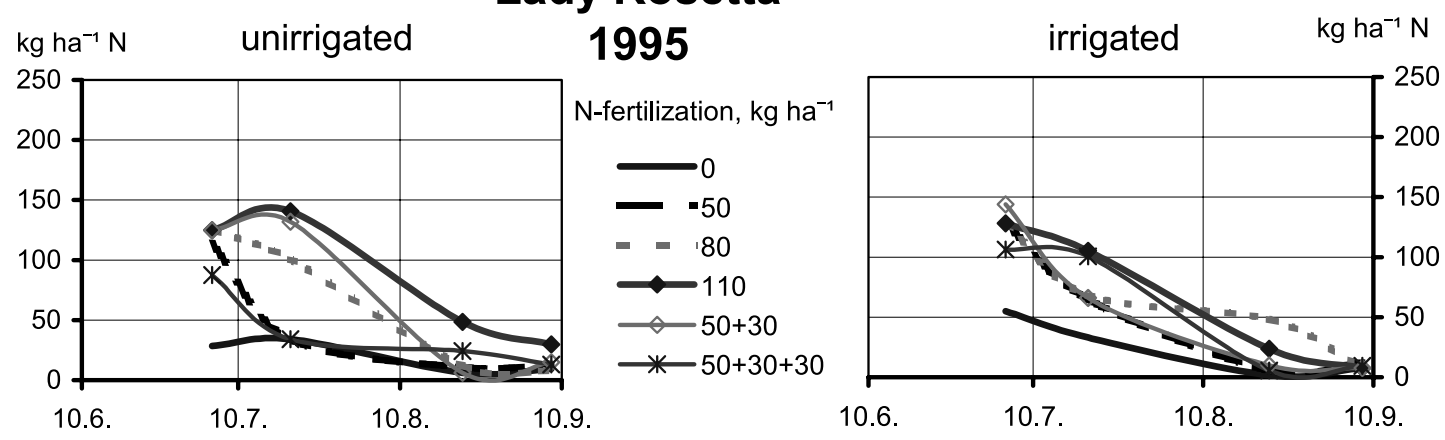

Fig. 3. Effect of irrigation and nitrogen fertilization on soil inorganic nitrogen in 1994-1995.

be seen, and the soil inorganic nitrogen stayed high on an unirrigated field up to the harvest. On irrigated plots the soil inorganic nitrogen decreased below $20 \mathrm{~kg} \mathrm{ha}^{-1} \mathrm{~N}$ at the beginning of August. At the harvest, the residual nitrogen in soil was about $10 \mathrm{~kg} \mathrm{ha}^{-1} \mathrm{~N}$, independently of nitrogen fertilization. In 1995 on cultivar Lady Rosetta, the changes of soil nitrogen were much more even than on varieties Fambo and Tanu in 1994. The effects of irrigation also were minimal, and the soil inorganic nitrogen was only slightly over $10 \mathrm{~kg} \mathrm{ha}^{-1} \mathrm{~N}$ on the unirrigated plots.

The level of tuber nitrate nitrogen content was in general very low, only 5 and $12 \mathrm{mg} \mathrm{kg}^{-1}$ tuber fresh weight on Fambo in 1994 and on 


\section{Kuisma, P. Split nitrogen fertilization with irrigation on potato}

Table 8. Effects of irrigation and nitrogen fertilization on nitrate content of tubers $\left(\mathrm{NO}_{3}-\mathrm{N} \mathrm{mg} \mathrm{kg}{ }^{-1}\right.$ tuber fresh weight) in 1994-1995.

\begin{tabular}{llcc}
\hline \multirow{4}{*}{ Irrigation } & $\begin{array}{l}\text { Fertilization } \\
\mathrm{kg} \mathrm{N} / \mathrm{ha}\end{array}$ & $\begin{array}{c}\text { Fambo } \\
1994\end{array}$ & $\begin{array}{c}\text { Lady Rosetta } \\
1995\end{array}$ \\
\hline Unirrigated & 0 & 2 & 9 \\
& 50 & 6 & 7 \\
& 80 & 8 & 2 \\
& 110 & 19 & 23 \\
& $50+30$ & 5 & 16 \\
& $50+30+30$ & 9 & 62 \\
Irrigated & 0 & 1 & 2 \\
& 50 & 1 & 4 \\
& 80 & 2 & 12 \\
& 110 & 1 & 10 \\
& $50+30$ & 1 & 15 \\
& $50+30+30$ & 8 & 10 \\
\hline
\end{tabular}

Lady Rosetta in 1995, respectively. However, higher values of residual soil nitrogen at harvest on unirrigated treatments resulted in a tuber nitrate content which was about triple compared to irrigated potatoes, and clearly higher due to high rates of fertilizer nitrogen or split application (Table 8). Johnson et al. (1996) also reported that on suboptimal nitrogen application a full irrigation resulted to lower nitrate concentration on tubers after harvest. On the irrigated field, the low residual nitrogen in soil after harvest shows that the potato crop can utilize nitrogen effectively in good soil moisture conditions (Fig. 4) as e.g. Carlsson (1977) and Johnson et al. (1996) reported.

Independently of cultivar or irrigation, the nitrogen uptake of tubers was $46-62 \mathrm{~kg} \mathrm{ha}^{-1}$ on unfertilized plots in 1994-1995. On fertilized treatments nitrogen uptake of tuber yield was related to given fertilization. Nitrogen uptake of tubers was clearly higher than the rate of fertilizer nitrogen (Fig. 4).

One kilogramme of nitrogen in tuber yield gave $301 \mathrm{~kg} \mathrm{ha}^{-1}$ tubers on fertilized plots when irrigation was not used, and $347 \mathrm{~kg} \mathrm{ha}^{-1}$ on irrigated potatoes. These were rather independent on used nitrogen fertilization and on the similar level as Joern and Vitosh (1995a) reported in Michigan. On the unfertilized plots, efficiency of nitrogen was clearly higher; $1 \mathrm{~kg}$ of tuber nitrogen produced a tuber yield, which was 412 $\mathrm{kg} \mathrm{ha}^{-1}$ on irrigated plots and $353 \mathrm{~kg} \mathrm{ha}^{-1}$ when irrigation was not used.

The apparent nitrogen recovery $(\mathrm{ANR}=$ $\left(\mathrm{N}\right.$-yield ${ }_{\mathrm{N} \text {-fertilized }}-\mathrm{N}$-yield $\left.{ }_{\mathrm{N}-0}\right) /$ fertilizer-N) (Novoa and Loomis 1981) of tuber yield in 1994 was on the average 0.68 and 0.58 on unirrigated Fambo and Tanu, respectively. When irrigation was used ANR was 0.99 and 0.79. On Lady Rosetta in 1995, ANR was independent of irrigation and slightly higher than on irrigated Fambo in 1994 (Table 9). On unirrigated potato in 1994, ANR was about on the same level as Guarda et al.

Table 9. Apparent nitrogen recovery in 1994 and 1995.

\begin{tabular}{llcccc}
\hline & & \multicolumn{2}{c}{1994} & & 1995 \\
\cline { 3 - 4 } \cline { 5 - 5 } Irrigation & $\mathrm{N} \mathrm{kg} \mathrm{ha}^{-1}$ & Fambo & Tanu & & Lady Rosetta \\
\hline Unirrigated & 50 & 0.83 & 0.58 & \\
& 80 & 0.88 & 0.64 & 1.14 \\
& 110 & 0.46 & 0.61 & 1.02 \\
& $50+30$ & 0.72 & 0.57 & \\
Irrigated & $50+30+30$ & 0.50 & 0.50 & \\
& 50 & 1.48 & 0.85 \\
& 80 & 1.01 & 0.74 & 0.94 \\
& 110 & 0.89 & 0.73 & 1.20 \\
& $50+30$ & 0.78 & 0.72 & 1.22 \\
& $50+30+30$ & 0.77 & 0.81 & 0.88 \\
& & & &
\end{tabular}


Vol. 11 (2002): 59-74.
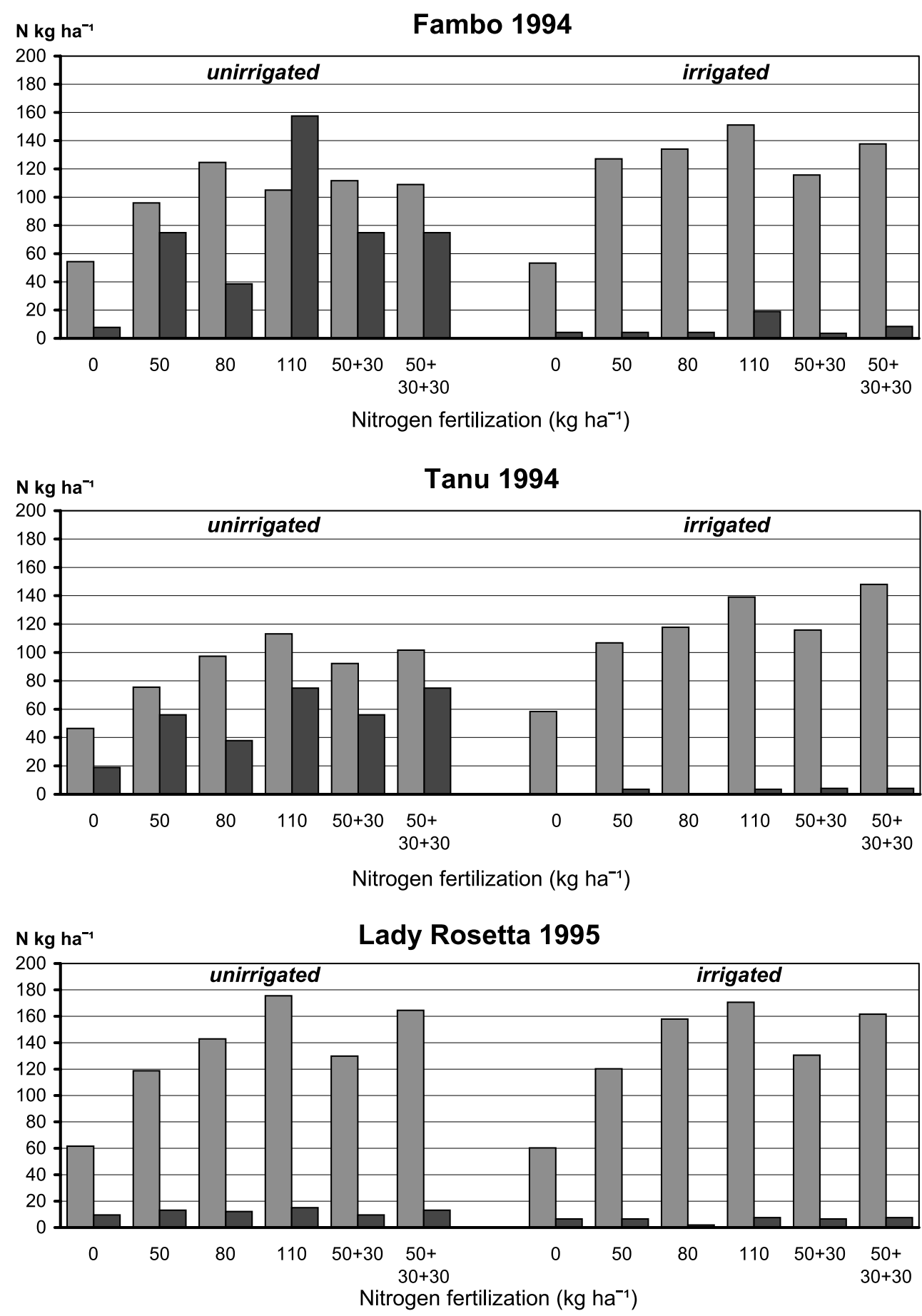

$\square \mathrm{N}$-yield in tubers $\quad \square$ Residual $\mathrm{N}$ in soil after harvest

Fig. 4. The balance sheet of nitrogen in 1994. 
(1993) noticed in Italy, but slightly higher than Molfetta et al. (1993) reported. In Michigan, USA, Joern and Vitosh (1995b) received a considerably lower recovery of fertilizer nitrogen. In their studies the tuber yield contained only $37 \%$ and the whole crop altogether $52 \%$ of applied nitrogen, independently of the nitrogen rate or application time. They also found $27 \%$ of fertilizer nitrogen to be in the soil $0-120 \mathrm{~cm}$ after harvest. Vos (1997) reported ANR-values 0.40.8 on whole plant basis. Guarda et al. (1996) reported that irrigation improved remarkably the efficiency of nitrogen fertilization in early potato. In this study the split application of nitrogen didn't improve the efficiency of fertilizer nitrogen as Westermann et al. (1988) reported.

\section{Conclusions}

The study showed that in general the split application of nitrogen fertilization isn't beneficial on potato in Finnish conditions when the recommended levels of fertilizer nitrogen are used. The most interesting result was to discover how very efficiently the potato crop utilises nitrogen sources in soil. From an environmental aspect the study proved that the use of fertilizer nitrogen according to general recommendations with irrigation, is not only a yield maximizing and most cost-effective but also a environmentally safe way to grow potato.

\section{References}

Allen, E.J. \& Scott, R.K. 1980. An analysis of the potato crop. Journal of Agricultural Science, Cambridge 94: 583-606.

Beukema, H.P. \& Zaag, D.E. van der. 1979. Potato improvement: some factors and facts. Wageningen: IAC. 224 p.

Boyoucos, G.J. 1950. A practical soil moisture meter as a scientific guide to irrigation practices. Agronomy Journal 42: 104-107.

Burton, W.G. 1989. The Potato. 3rd ed. New York: Longman Scientific \& Technical. $742 \mathrm{p}$.

Carlsson, H. 1977. Bredspridning och radmyllning av kvävegödsel till potatis. Olika tidpunkter och olika markfuktighet. Rapporter och avhandlingar 57. Uppsala: Lantbrukshögskolan Institutionen för växtodling. $19 p+$ appendixes.

Carlsson, H. 1988. Gödselplacering i potatis. Rapporter och avhandlingar 183. Uppsala: Lantbrukshögskolan Institutionen för växtodling. 25 p.

Carlsson, H. 1995. Application of fertilizers in different ways to potatoes in Sweden. Abstracts of papers of the joint meeting of the agronomy and utilisation sections of the EAPR, Vila Real 23-30 June 1995. p. 28-29.

Elonen, P., Nieminen, L. \& Kara, O. 1967. Sprinkler irrigation on clay soils in southern Finland I. Sprikler irrigation, its technique and effect on soil moisture. Journal of Agriculture Society of Finland 39: 67-77.

Gavlak, R.G., Campbell, W.L., Walworth, J.L., Johnson, C.L., Muniz, J.E. \& Tindall, T.A. 1993. Nitrogen fertilization of irrigated Russet potatoes in Southcentral
Alaska. American Potato Journal 70: 571-578.

Goffart, J.-P. \& Guiot, J. 1996. Influence of timing and type of $\mathrm{N}$-fertilizer on $\mathrm{N}$-uptake and yield of potato and soil mineral nitrogen status in Belgian loam soils. Abstracts of Conference Papers, Posters and Demonstrations of the $13^{\text {th }}$ Triennial Conference of the EAPR, Veldhoven 14-19 July 1996. p. 391-392.

Guarda, G., Giovanardi, R. \& Tassoni F. 1990. Effect of irrigation and nitrogen on potato (Solanum tuberosum L.) of: 1) yield, dry matter content and crisps quality. Abstracts of Conference Papers and Posters of the $11^{\text {th }}$ Triennial Conference of the EAPR, Edinburgh 8-13 July 1990. p. 180-181.

Guarda, G., Giovanardi, R., Dalla Costa, L. \& Chillemi, G. 1993. Efficiency of nitrogen on four potato cultivars for industrial uses. Abstracts of the $12^{\text {th }}$ Triennial Conference of the EAPR, Paris 18-23 July 1993. p. 427-428.

Guarda, G., Colauzzi, M., Tassoni, F. \& Zuffellato, F. 1996. Effect of nitrogen fertilization and water supply on the growth of an early potato (Solanum tuberosum L.) cultivar. Abstracts of Conference Papers, Posters and Demonstrations of the $13^{\text {th }}$ Triennial Conference of the EAPR, Veldhoven 14-19 July 1996. p. 95-96.

Hack, H., Gall, H., Klemke, Th., Klose, R., Meier, U., Stauss, R. \& Witzenberger, A. 1993. The BBCH scale for phenological growth stages of potato (Solanum tuberosum L.). Abstracts of the $12^{\text {th }}$ Triennial Conference of the EAPR, Paris 18-23 July 1993. p. 153154. 
Vol. 11 (2002): 59-74.

Harris, P.M. 1978. Mineral nutrition. In: Harris, P.M. (ed.). The Potato Crop. London: Chapman \& Hall. p. 195-243.

Harris, P.M. 1990. Effect of irrigation and fertilizer nitrogen on the growth, yield and light utilization of two contrasting potato cultivars. Abstracts of Conference Papers and Posters of the $11^{\text {th }}$ Triennial Conference of the EAPR, Edinburgh 8-13 July 1990. p. 178-179.

Hunnius, W., Bachthaler, G. \& Munzert, M. 1972. Zum Einfluß des Stickstoffs auf die Vollernteverträglichkeit der Kartoffelknolle. Potato Research 15: 54-66.

Hveem forsøksgard 1991. Forsøk med delt gjødsling. In: Forsøksmelding 1992. Hveem: Norske Potetindustrier. p. 36-39.

Joern, B.C. \& Vitosh, M.L. 1995a. Influence of applied nitrogen on potato. Part 1: yield, quality, and nitrogen uptake. American Potato Journal 72: 51-63.

Joern, B.C. \& Vitosh, M.L. 1995b. Influence of applied nitrogen on potato. Part 2: recovery and partitioning of applied nitrogen. American Potato Journal 72: 7384.

Johnson, P.A., Shepherd, M.A. \& Lord, E.I. 1996. Loss of nitrogen by leaching after potato crops: experimental and field evidence. Abstracts of Conference Papers, Posters and Demonstrations of the $13^{\text {th }}$ Triennial Conference of the EAPR, Veldhoven 14-19 July 1996. p. 91-92.

Kangas, A. 1998. Tärkkelyspitoisuuden määritys. In: Järvi, A. et al. Virallisten lajikekokeiden suoritusohjeet. Maatalouden tutkimuskeskuksen julkaisuja. Sarja B 14. p. 49.

Kangas, A. 1998. Ulkoinen laatu. In: Järvi, A. et al. Virallisten lajikekokeiden suoritusohjeet. Maatalouden tutkimuskeskuksen julkaisuja. Sarja B 14. p. 51-52.

Kemira Agro Oy 1994. Maaperälaukun käyttöohje. 23 p. (Mimeograph)

Kuisma, P. 1998. Sadetuskokeista esille saatua. Tuottava Peruna 25, 2: 30-31.

Leppänen, A. \& Esala, M. 1995. Keväisen mineraalityppianalyysin käyttö lannoitetypen ennustamiseen. Maatalouden tutkimuskeskuksen tiedote 1/95. 29 p.

Linden, B., Lyngstad, I., Sippola, J., Søegaard, K. \& Kjellerup, V. 1992. Nitrogen mineralization during the growing season. 1. Contribution to the nitrogen supply of spring barley. Swedish Journal of Agricultural Research 22: 3-12.

Linnér, H. 1988. Växtnäringsstyrning till potatis. In: Potatisfrågor. NJF-seminarium Uppsala 8-9 March 1988. p. 6-10.

Loon, C.D. van, Slangen, J.H.G. \& Houwing, J.H. 1987. Nitrate content of leaf petioles as a quide to optimazion of $\mathrm{N}$-fertilization of ware potatoes. Abstracts of Conference Papers and Posters of the $10^{\text {th }}$ Triennial Conference of the EAPR, Aalborg 26-31 July 1987. p. $146-147$.

MacLean, A.A. 1984. Time of application of fertilizer nitrogen for potatoes in Atlantic Canada. American Potato Journal 61: 23-29.

Molfetta, P., Ceccon, P., Guarda, G. \& Dalla Costa, L. 1993. Nitrogen use efficiency and uptake patterns of potato (Solanum tuberosum L.) as affected by fertilization rate. Abstracts of the $12^{\text {th }}$ Triennial Conference of the EAPR, Paris 18-23 July 1993. p. 53-54.

Mustonen, L. 1997. Perunalajikkeiden typpilannoitus. Abstract: Nitrogen fertilization of table potato cultivars. Maatalouden tutkimuskeskuksen julkaisuja. Sarja A 20. 31 p.

Nitsch, A. \& Varis, E. 1991. Nitrate estimates using the Nitrachek Test for precise $\mathrm{N}$-fertilization during plant growth and, after harvest, for quality testing potato tubers. Potato Research 34: 95-105.

Novoa, R. \& Loomis, R.S. 1981. Nitrogen and plant production. Plant Soil 58: 177-204.

Ojala, J.C., Stark, J.C. \& Kleinkopf, G.E. 1990. Influence of irrigation and nitrogen management on potato yield and quality. American Potato Journal 67: 29-43.

Perunantutkimuslaitos 1985 . Typpi- ja fosforilannoituksen ajoituskoe. Perunantutkimuslaitoksen koetuloksia 1984. Perunantutkimuslaitoksen julkaisu 1/1985. Lammi: Perunantutkimuslaitos. p. 57-60.

Ruippo, J. \& Alikärri, O. 1989. Pikamenetelmän käyttö perunan laadun määrittämiseen - nitraatti. kalium, glukoosi ja C-vitamiini. Tutkimusraportti 5. Perunantutkimuslaitoksen julkaisuja 3/89. Lammi: Perunantutkimuslaitos. 19 p.

Sieczka, J.B., Kossowski, J. \& Rybus, I. 1993. Techniques to maximize nitrogen efficiency and minimize ground water contamination in humid climates. Abstracts of the $12^{\text {th }}$ Triennial Conference of the EAPR, Paris 1823 July 1993. p. 307-308.

Snedecor, G. 1956. Statistical methods applied to experiments in agriculture and biology. $5^{\text {th }}$ ed. Ames, lowa: The lowa State College Press. $534 \mathrm{p}$.

Svensson, E., Johansson, O. \& Jónsson, L. 1973. Försök med kvävegödsling till fabrikspotatis. Intensitet och fördelning: Försöksserie FK-S 64. Lantbrukshögskolans meddelanden A 206. Uppsala: Lantbrukshögskolan. $31 \mathrm{p}$.

Varis, E. 1972. The effects of increasing NPK rates on the yield and quality of the Pito potato. I. Tuber yield, starch content and starch yield. Acta Agralia Fennicae 128: 3-20.

Vos, J. 1997. The nitrogen response of potato (Solanum tuberosum L.) in the field: nitrogen uptake and yield, harvest index and nitrogen concentration. Potato Research 40: 237-248.

Vos, J. \& Marshall, B. 1993. Nitrogen and potato production: strategies to reduce nitrate leaching. Abstracts of the $12^{\text {th }}$ Triennial Conference of the EAPR, Paris 18-23 July 1993. p. 305-306.

Walther, U. 1984. Untersuchungen über den Einfluss des N-Düngungstermins auf Ertrag und Qualität von Kartoffeln in Hinblick auf eine mögliche Verbesserung der N-Ausnutzung. Abstracts of Conference Papers of the $9^{\text {th }}$ Triennial Conference of the EAPR, Interlaken 1-6 July 1984. p. 266-267.

Westermann, D.T., Kleinkopf, G.E. \& Porter, L.K. 1988. Nitrogen fertilizer efficiencies on potatoes. American Potato Journal 65: 377-386. 
Kuisma, P. Split nitrogen fertilization with irrigation on potato

\title{
SELOSTUS
}

\section{Jaetun typpilannoituksen käyttömahdollisuudet perunalle}

\author{
Paavo Kuisma \\ Perunantutkimuslaitos
}

Suurten typpimäärien antaminen lannoituksessa yhdellä kertaa on riskialtista. Runsas lannoitetyppi kasvukauden alussa voi viivästyttää perunan kehitystä niin, että kasvustot eivät ehdi tuleentua riittävästi ennen sadonkorjuuta. Osa keväällä istutuksessa annetusta lannoitetypestä saattaa myös huuhtoutua pohjavesiin runsaan sateen tai sadetuksen seurauksena, sillä perunaa viljellään yleensä keveillä, helposti läpäisevillä maalajeilla. Keskieurooppalaisissa ja myös ruotsalaisissa tutkimuksissa suurten lannoitetyppimäärien jakamisesta useampaan lannoituskertaan on saatu hyviä tuloksia. Jaettua typpilannoitusta käytetäänkin jossain määrin käytännön viljelyssä.

Perunantutkimuslaitoksella tutkittiin vuosina 1993-1995 kenttäkokeessa sadetukseen liitettynä perunan typpilannoitustarvetta ja suurimpien lannoitemäärien jakomahdollisuuksia suomalaisessa perunantuotannossa. Muuten viljelytekniikassa pyrittiin hyödyntämään mahdollisimman hyvin kaikki perunan kasvua aikaistavat toimet.

Tutkimus osoitti, että kasvuoloissamme typpilan- noituksen jakamisesta ei ole hyötyä, kun pitäydytään lannoitussuositusten mukaisissa typpimäärissä. Keskimäärin parhaat sadot saatiin, kun kaikki lannoitetyppi annettiin istutuksen yhteydessä. Tutkimus toi myös esille, että peruna käyttää tehokkaasti hyväkseen kasvukauden aikana maasta mobilisoituvan typen, jos vesitaloudesta pidetään hyvää huolta esimerkiksi sadetuksella. Tästä osoituksena olivat kuivan heinäkuun 1994 noston jälkeen sadettamattomassa maassa olleet yli $100 \mathrm{~kg} / \mathrm{ha}$ typpimäärät. Sadetetussa maassa ja kosteampana kesänä 1995 maasta löytyi liukoista typpeä noston jälkeen noin kolmannes niistä määristä, mitä keväällä oli istutusvaiheessa.

Parhaimmillaan typpilannoituksen näennäinen hyväksikäyttö sadossa oli yli yhden osoittaen, että lannoitetun perunakasvuston kyky ottaa käyttöönsä maan luontaisia typpivaroja oli itse asiassa parempi kuin ilman typpeä viljellyn perunan. Ilman typpilannoitusta perunasadossa pellosta poistuvat typpimäärät olivat 46-62 kg N/ha, ja lannoitetussa perunassa keskimäärin 76-176 kg N/ha. 